\title{
Sonata in Fis-Moll as an Example of the Romantic Style in R. Schuman's Music
}

\author{
Olga D. Dobroshinskaia \\ and Maria V. Kholodova* \\ Krasnoyarsk State Institute of Arts \\ 22 Lenin Str., Krasnoyarsk, 660049, Russia
}

Received 01.04.2016, received in revised form 20.05.2016, accepted 01.08.2016

Robert Schumann is a prominent representative of the Romantic era. The article discusses the features of the composer's piano style in the context of the romantic music art and, in particular, the piano sonata No.1 in fis-moll, which is the centre of subjectively lyrical reflections of Schumann. It, as the other piano works of the "turbulent" 30's, demonstrates bright reflection of the romantic selfconsciousness and the key principles of the Schumann romanticism, the main features of $R$. Schumann's creative method, wealth of an emotionally-figurative structure, individuality of a pianistic manner.

Keywords: R. Schumann, musical romanticism, romantic style, piano sonata.

DOI: 10.17516/1997-1370-2016-9-8-1812-1821.

Research area: culture studies.

The name of a brilliant German composer Robert Schumann is considered to be a symbol of romanticism in the history of world music.

Against the background of Western European art of the first half of the $19^{\text {th }}$ century Schumann stands out due to the burning passion of his music, amazing spiritual wealth and bold innovation in the figurative and genre fields (Polezhaeva, 2014).

Continuing the tradition of German Romanticists, he pushed the boundaries of music and proved that it is able to "shed light into the depths of the human heart - this is the mission of the artist" (Schumann, 1970: 128). These words of the composer himself describe the spiritual essence of his work.
Schumann's musical heritage is rich and diverse in terms of genre: it is opera, symphonic music, chamber-instrumental and vocal compositions. However, the piano music holds a special place in the creative portfolio of the German composer - it is his most important and intimate sphere of lyrical expression. It is also important for us that it fully concentrates romantic tendencies.

The 30 's of the $19^{\text {th }}$ century is a period for blossom of the romantic attitude of Schumann. This is the time of creation of the famous "Carnival", "Symphonic Etudes" and other opuses that opened a brand new, bright page in the piano music. Among the works of the Schumann's rapid ascent, an important place is occupied by three piano sonatas.

(c) Siberian Federal University. All rights reserved

* Corresponding author E-mail address: dobrod227@mail.ru; holodova-maria@mail.ru 


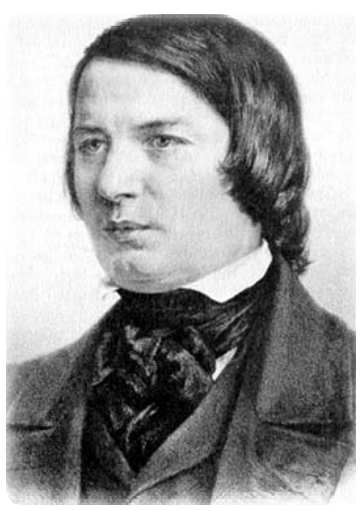

Fig.1. R. Schumann

As is known, a sonata in different historical periods has always been a certain "battlefield" of different stylistic traditions, a centre of searches in the field of expression means, image-compositional solutions, revealing subtle gradations of the psychological world of their authors (Il'icheva, 2010). Schumann sonatas are no exception - they combine features of his creative method, richness and depth of the imageemotional structure, bright individuality of the pianistic manner.

Schumann's attitude to the genre of sonata was largely "transformative", since being a Romantic artist he sought to its renewal, enrichment with new images and means of expression, a synthesis of the sonata form with obtainment of new principles (including his own) of romantic music forms: program cycles, miniatures, fantasy, concert.

Without rejecting the classical structure of a four-part sonata-symphonic cycle, R. Schumann innovatively approach to solving the first and the final movements showing a protest against the "tyranny" of mandatory laws of the sonata form.

Thus, for example, the composer does not think much of a motive-thematic development with its analytic principle. He organizes the musical process as a contrastively renewing chain of thematic compositions, repeats, variations. It means that $R$. Schumann is more attracted to the multiple image display in the unity, which determines the priority of refrainness.

The forms of finales have a greater variety of interpretations, where two conflicting structural principles, rondo and sonata form, actively interact with each other. The aesthetic justification of such an approach to the form is seen by the researchers in Schumann's characterization of Schubert's sonatas and symphonies in C-dur, where he insanely admired "divine prolixities" that can be read like an entertaining novel (Zhitomirskii, 2000: 265-274).

Thus, R. Schumann created a sort of a romantic-type "kaleidoscopic" sonata. At the same time, the composer set himself an important problem of integrity implemented at all levels in an ideological and imaginative concept, structure, intonation field of the composition, with its tendency towards monothematicism as a principle of thinking.

All three piano sonatas had literally been "spilled out on paper" in the course of 1835. This fact of extraordinary fertility of the musician in this period of time is not accidental and, of course, is connected with the events of his personal life his bonding with Clara:

“...On September 13, 1835, Clara celebrated her sixteenth birthday with the Davidsbündler society. Ernst Ortlepp read poems, Mendelssohn played her Capriccio four hands, and then cleverly imitated the play of Liszt and Chopin, Clara played Bach's fugue, and, by a special request of Mendelssohn - Scherzo from the sonata in fismoll by Schumann that was dedicated to her by "Florestan and Eusebius". Their hearts had been getting more closely to each other. On one autumn evening of the same year, when Clara, as usual, accompanied Robert to the stairs with a candle, they shared the first words of love confession" (Zhitomirskii, 2000: 152-153).

Schumann's biographers aptly called the second half of the 1830's "the time of the fight for 


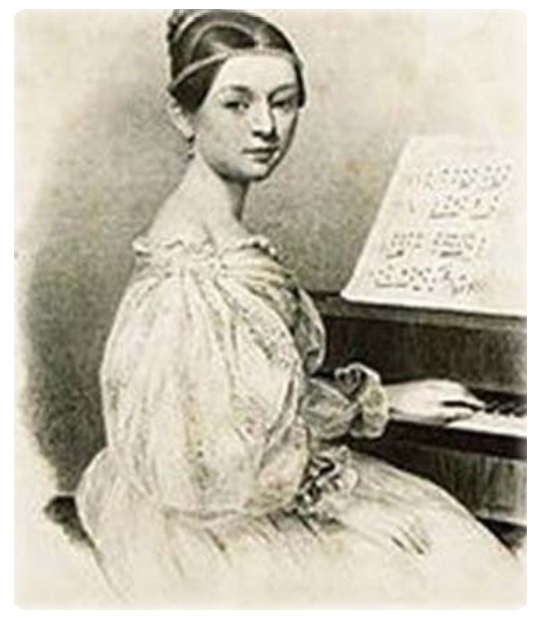

Fig.2. Clara Wieck

Clara", when he desperately defended the right to his love. It is symptomatic that almost all the piano works of this period have a pronounced autobiographical character (which is typical of romanticists in general) revealing the profound spiritual experiences of the musician. In particular, the three piano sonatas of the composer are fully related to Clara and affection for her.

This is confirmed, first of all, by the composer's letters and by the thematic material of the works, which is based on musical themes of Clara Wieck (Sonata number 1, 3).

The First and the Third Sonatas are close in their conflict dramaturgy, imaginative plan, forming a kind of arch in a triad of sonatas. All researchers call the Second Sonata the most chamber-like. This is one of the most luminous and lyrical pages of the Schumann "heart diary" that was created, of course, at the moment of soulful improvisation of the musician in love. "The Second Sonata infinitely pleases me, Clara Wieck wrote to the author, it reminds me of many happy and sad hours. I love it the same way I love you; your entire being etched so clearly in it..." (Zhitomirskii, 2000: 314).

In our opinion, the three sonatas form a kind of a macrocycle, wherein the First and the Third are the dramatic allegro and finale, while the
Second is a lyrical and philosophical centre of the utterance. In support of this assertion we should note a cross-cutting time of creation, a "hidden story", unity of imaginative sphere and principles of dramaturgy.

This macrocycle could also probably include the Fantasie in C-dur - one of the topmost works by R. Schumann that initially was entitled by the composer as "Grand Sonata". Firstly, this composition was written in a close period of time of creating sonatas (1836) and is included in the overall imaginative sphere - it is related to the theme of love for Clara and a painful fight for her:

"You can only understand the Fantasie if you go back to the unhappy summer of 1836 when I renounced you. $<\ldots>$ Does it not call up pictures in you? $<$.. > I like the melody the most. Is it possible that the 'tone' in the motto is you? I almost believe it $<\ldots>$ The first movement may well be the most passionate I have ever composed - a deep lament for you", the composer wrote to Clara Wieck (Schumann, 1970, 462, 478, 346).

Secondly, there are repeated basic principles of a romantic, lyrical and psychological type of the sonata dramaturgy, which found concentrated expression in the earlier sonatas.

The First Sonata, perhaps, has the most romantic concept. Schumann always spoke of it as of a very dear page of his personal life. So, when he sent the Sonata to H. Keferstein in 1837, he wrote, "Take a look at it with love, and it will love you back. There are many bloodstains on it" (Zhitomirskii, 2000: 309).

The sonata cycle starts with a great Introduction bearing the imprint of Beethoven's heroics. A nature of the Introduction is determined by the powerful energy of the first, Florestan theme, which is one of the most important in the composer's creative work. It holds a major impulse concentrating typical features of the Schumann thematic invention embodying a passionate impulse and spiritual aspiration. 
The oratory principle of a fanfare-like melody, its energetic fourth-chord ascent - all of this creates a strong-willed image that inherits traits of the Beethoven's heroic thematic invention. However a hammered ostinato rhythm, gloomy minor colouring of the theme and a harmonic chain of suspended tones bring the theme together with marches funèbre:

At the same time, the heroic pressure is smoothed by the softness and the swaying waviness of the "nocturne" figurations accompanying the theme, which gives the courageous image a romantic flavour.

The second theme of the Introduction (A-dur) is associated with Eusebius. The obvious vocal nature of cantilena, song-and-romance intonations and melodious figurations of accompaniment give the theme a sophisticated, dreamy character defining the lyric nature of the sonata drama.

Let us note the intonational similarity to the First theme (figures of accompaniment, dotted rhythm, veiled fourth-chord step), which emphasizes the figurative-semantic unity - after all it is the two contrasting portraits of the lyrical hero:

The first movement has a number of new expression techniques that are incredible within the classical traditions of sonatas by Haydn, Mozart, and Beethoven. They give the Schumann's sonata Allegro a pronounced romantic character.

The sonata allegro based on variation is monothematic, since a rebellious image of the primary area prevails here capturing both exposition and development.

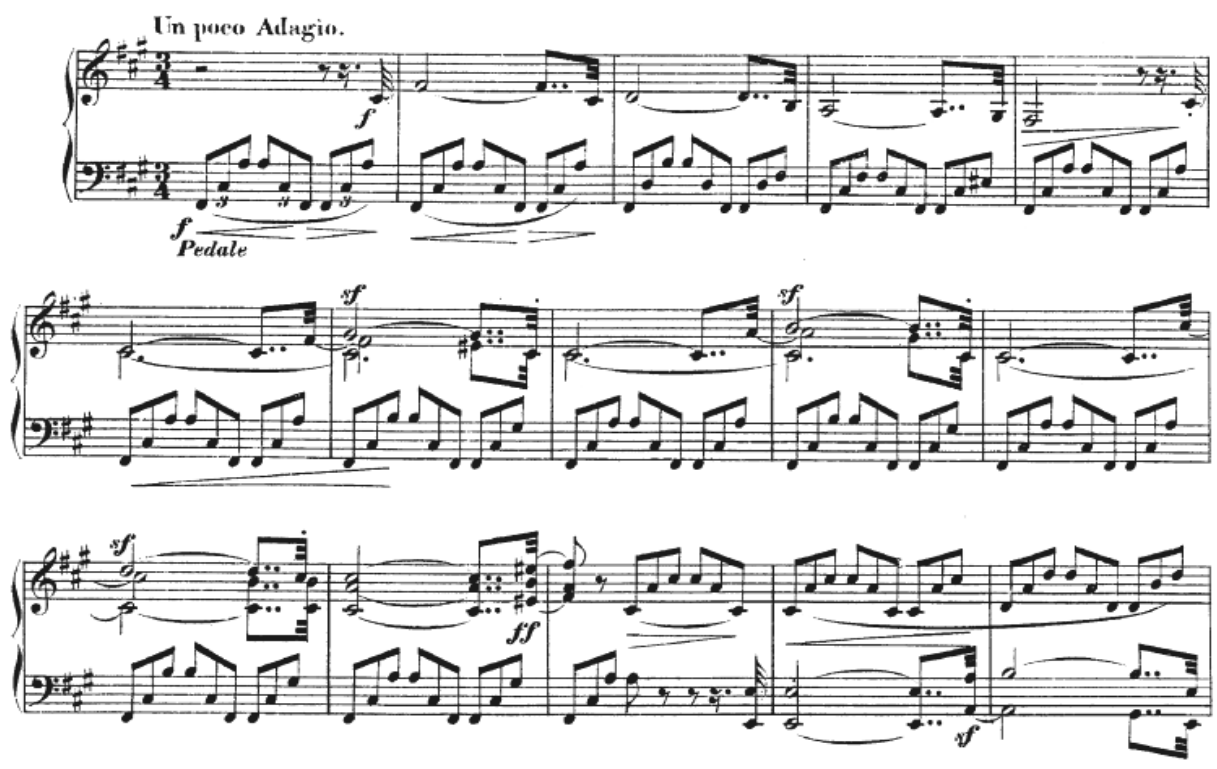

Fig. 3

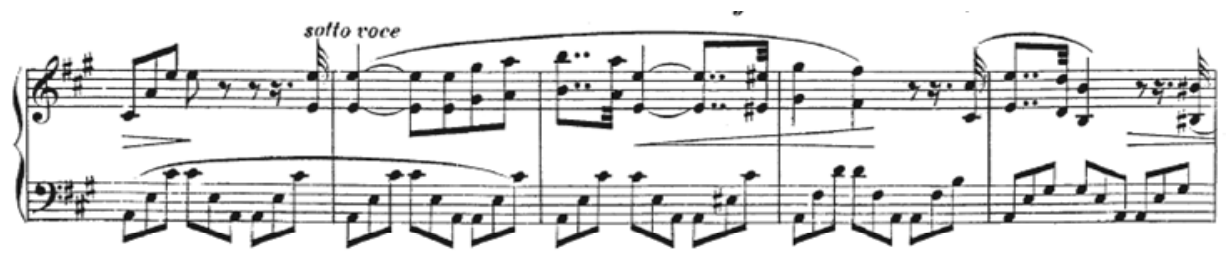

Fig. 4 
The first theme of Allegro is written in the rhythm of a Spanish dance fandango:

It is related to the theme of the Introduction (inversion of the initial fourth-chord intonation in the second theme of the introduction). A melodic core of the primary area and its rapid rise seem to be a response to a quint bass motif that serves as the motto and permeates not only the sonata allegro, but becomes one of the cross-cutting thematic elements of the entire sonata.

Each new development of the theme is dynamized by the enhanced sound of the motto. The constant conflicting presence of this staccato motif in the sonata allegro, its participation in the process of thematic development, transformation of the main theme are the main features of implementation of the symphonic principle that relates Schumann to Beethoven.

This theme is known to have originated on the basis of the play by Clara Wieck "Ballet of the ghosts. Fantastic scene" op. 5 under the title "Four Characteristic Pieces". It has been suggested that the theme of Clara Wieck was first used in Schumann's unpublished piano piece "Fandango"
(1832), and then became a central theme of the sonata in fis-moll.

Citing “Clara's music” reveals a psychological program of the movement. At the same time, the use of the piano play as the primary area of the sonata allegro explains a lot in the romantic and individual features of the Schumann's sonata. As noted by N. Nikolaeva, the Spanish dance has given the necessary rhythmic pulse and the nature of the movement that are so important for the emotional tone of the composition: "If Schubert dramatized a song in a symphony, Schumann dramatized a dance in a sonata". Here, let us note that dance dramatization is a characteristic feature of the Florestan sphere of Schumann's music in general.

Let us note another difference from the classical traditions. A new theme in the key of esmoll is referred to as a binder, but it is so close to the main key that it is perceived as its variation:

Primary area and transition are built by the composer in a detailed ternary form of an open type (the structure typical of the primary areas by Tchaikovsky, some themes by Mahler).

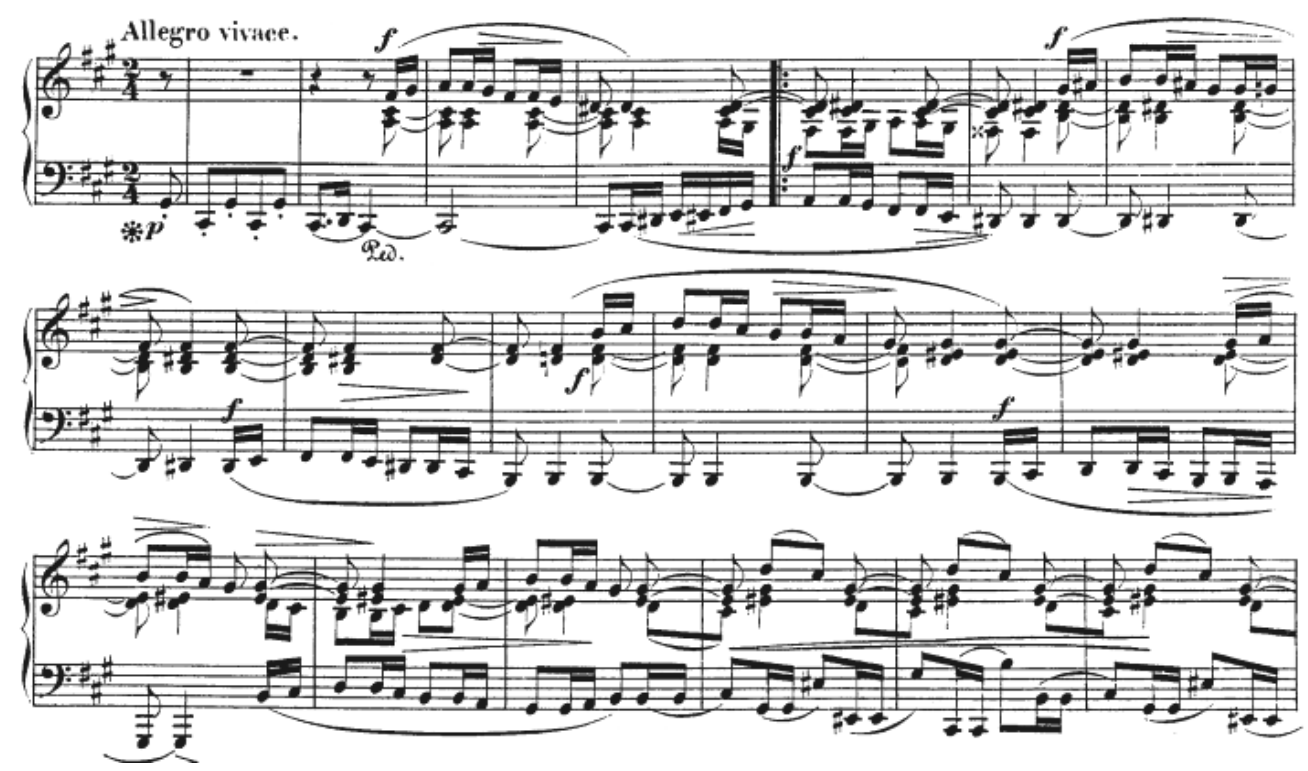

Fig. 5 
The composer's secondary area is shifted to the end of the exposition taking the place of the closing area. It creates a vivid imaginativesemantic contrast for the dramatic-expressive Allegro - "a ray of light" in a tense, seething element of feelings.

This is, of course, the "Eusebius" theme that is associated with the image of a romantic dream (Clara), dreams of love. Hence the light, idyllic A-dur, the contrast change of texture to a homophonic-harmonic (with sustained fifthchord bass) vocal nature of lyrical cantilena, soft endings of descending conjunct phrases. Although the intonational unity with the main theme is obvious (the principle of descending melodies, fifth-chord accompaniment):

A Schumann's typically romantic technique in rethinking a secondary theme in the reprise, where it elegiacally sounds in a minor key, the initial rhythmic figure creates a sense of doomness, and the "bourdon" bass now creates the effect of a fading dream as a result of an unequal tense struggle:

Speaking about the non-classical features of the first movement, let us note that most of the exposition becomes the scope of the Florestan image - the primary area acting in different variations. The secondary area - the Eusebius theme - is a lyrical epilogue in the exposition, which is contrary to the general principle of the sonata form highlighting the principle of monologueness that is characteristic of romantic Schumann.

Thus, there is a non-traditional, inner cycle of exposition with a lyrical epilogue and a cross-cutting principle of development typical of Schumann. However, as a result of the shift, the central antithesis necessary for the sonata dramaturgy has not disappeared. It is implemented by the metamorphosis of the secondary area forming a contrast of the sonata order with the primary area.

The second and third movements perform the function of the suspension and play an "intermediary" role in the claimed conflict, the main dramaturgical role in disclosure of which goes to the final movements of the sonata.

The title of the second movement emphasizes a romantic nature of music. "Aria" is a wonderful example of Schumann's light, delicate-intimate lyrics. In order to emphasize the intimate, lyrical character of the miniature, the composer quotes one of his songs from an unpublished notebook ("To Anna"). A vocal nature of the theme is obvious, and the musical development is built as a kind of a dialogue:

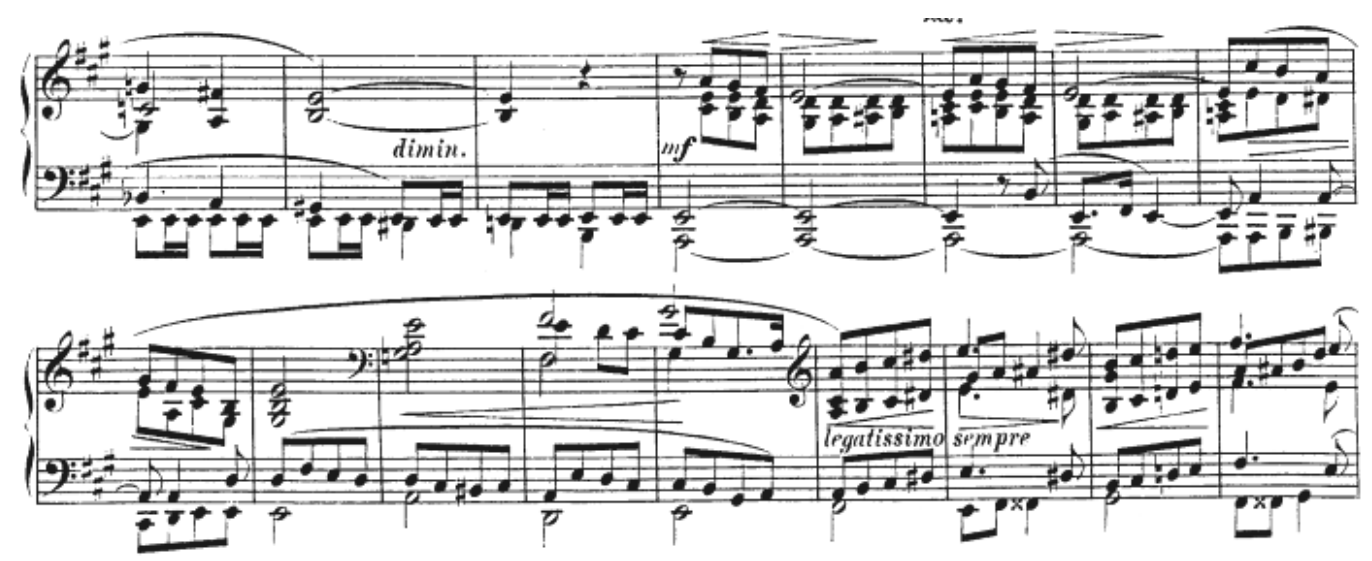

Fig. 6 
The third movement of Scherzo is a traditionally dance sphere of the statement. It forms the inner cycle with contrasting alternation of the characteristic images.

A figurative-dramaturgical concept of the first movement continues in the finale. The main theme of the finale is intonationally close to the primary area of the first Allegro - a rapid marchlike refrain-theme is perceived as a kind of its dynamized variant. Thus, the composer creates a figurative-semantic arch bringing the lyrical hero of the sonata with his feelings back to the forefront:
Compared with the first movement, in the finale there is a weakening of sonata principles and highlighting of the rondo cyclicity. The unusual finale is combined with principles of rondo and sonata without development. The initial theme is a refrain, the development of which divides the composition into two large cycles and one reduced cycle. The first two cycles, similar in general terms of exposition and development, in turn, are divided into "small" cycles that are also demarcated by developments of the refrain. The third cycle that does not include secondary themes is a coda.

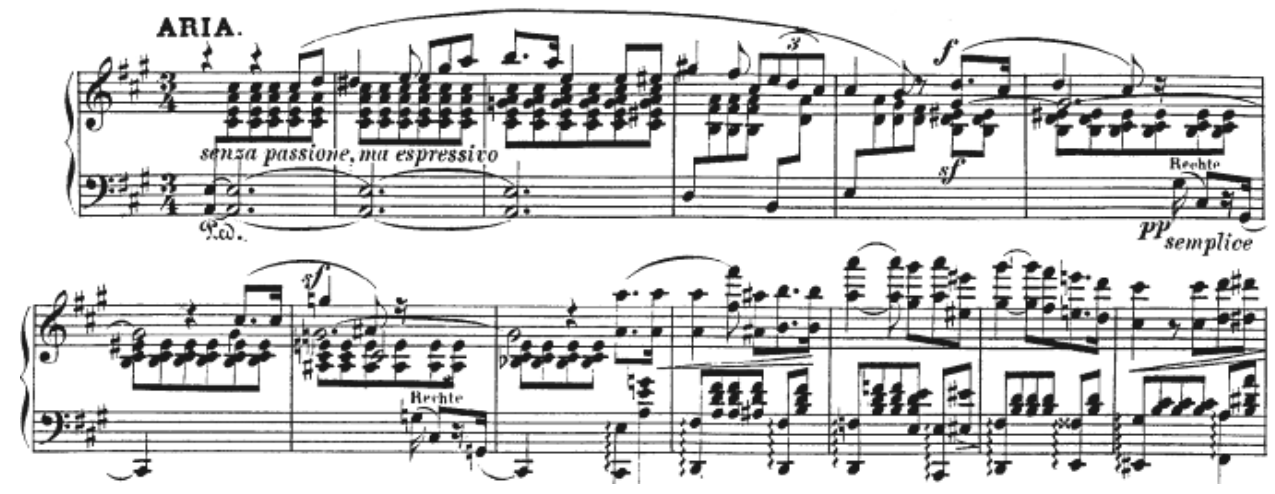

Fig. 7

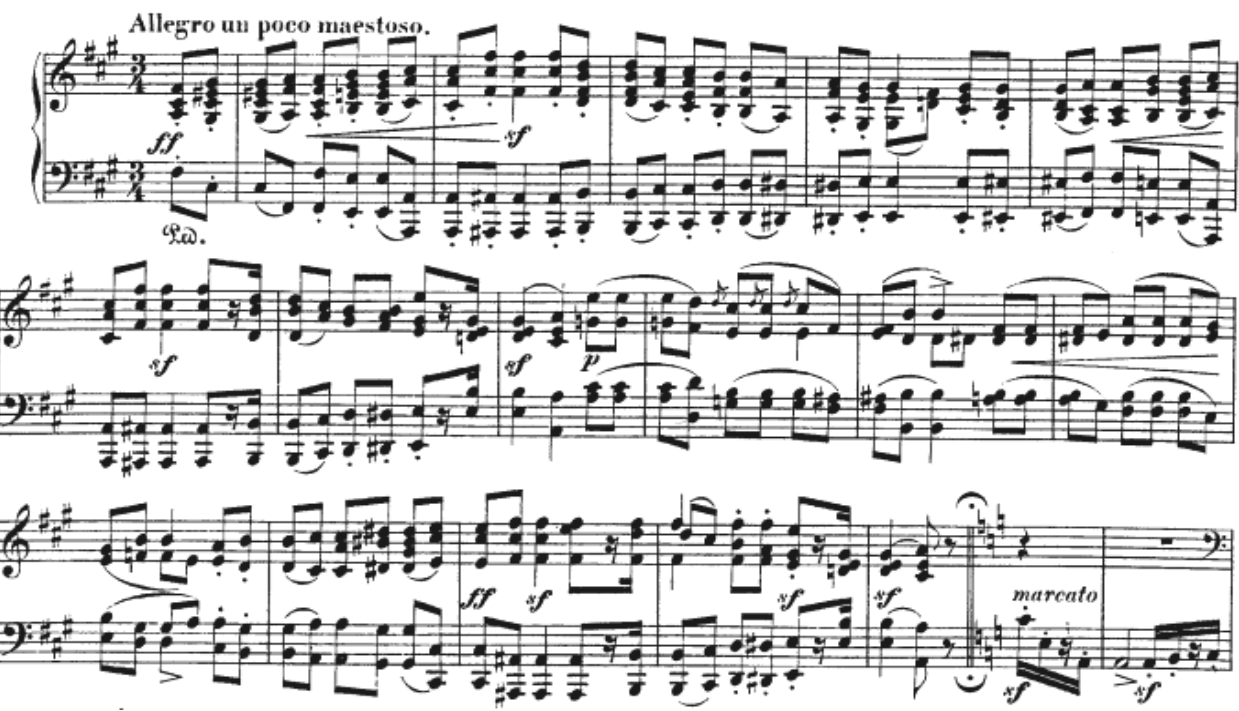

Fig. 8 


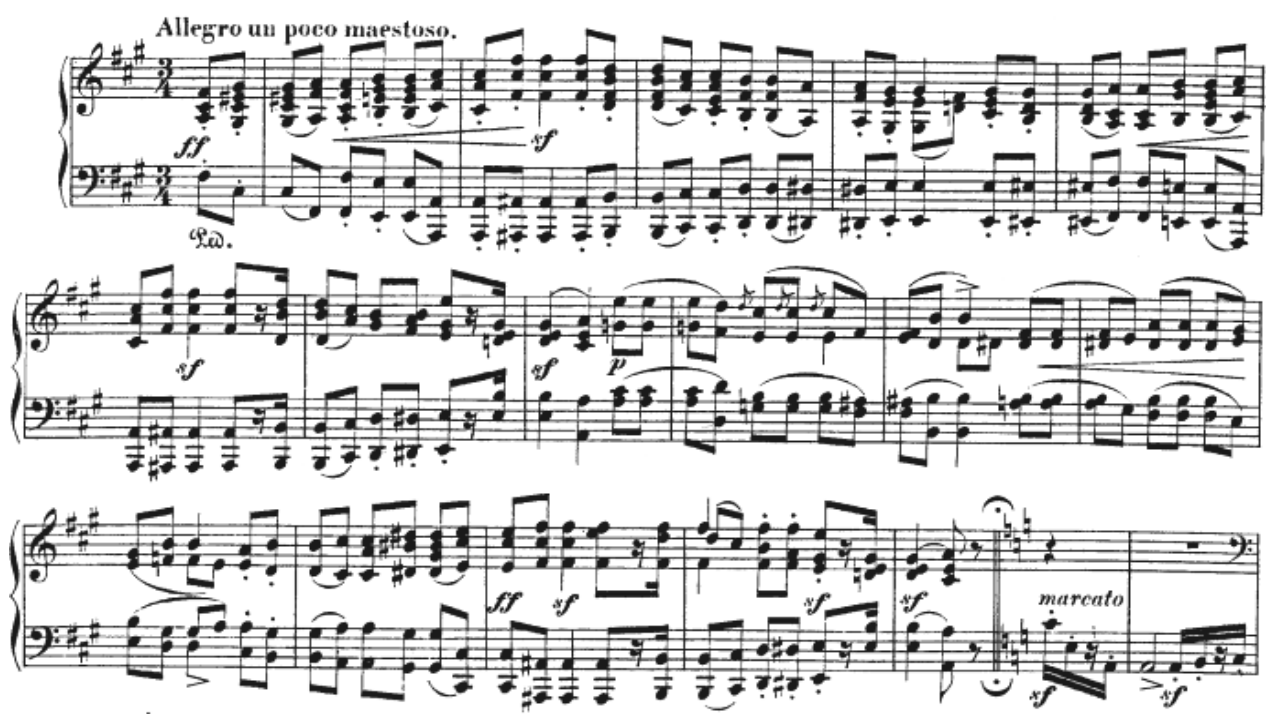

Fig. 9

N. Nikolaeva identifies two opposing trends in the finale formation (Muzyka Avstrii i Germanii XIX veka, 1990: 45). First of all, it is a trend towards concentration associated with the unification of all the images around the antithesis Florestan - Eusebius stated in the introduction. The cross-cutting imaginative and thematic development of the sonata is also sealed by tonal dramaturgy. The ratios in the introduction, fismoll - A-dur, create a tonal frame of all parts of the cycle written by the Beethoven's principle "from darkness to light", which ends with the same-name majeure.

Another trend towards dispersion is expressed in polythematism that is non-traditional for the sonata form, branching of contrasts (thematic and tonal), a set of repetitions, variants, and deviations from the main thread of the narrative. This reflects a fundamental difference with the classical sonata dramaturgy.

Thus, Sonata No.1 in fis-moll is the centre of the Schumann's subjective-lyrical reflections. Like the other piano works of the "turbulent" 30 's, it reflected romantic self-consciousness and programmed key principles of Schumann's romanticism.
By telling "his 'story of bitter anguish', his Kreisleriana" R. Schumann is inseparable from the traditions of the German and the world classical music. In his creative work there are strong stylistic connections with J.S. Bach, L. van Beethoven and F. Schubert. But when we listen to the music, "we always feel that it is Schumann his breathing, his temperament, his unusual, acute perception of life" (Zhitomirskii, 2000: 35).

The directed formation of a single imagesemantic line throughout all movements of the sonata, emerging intonation-thematic correlations and arch connections cement the cycle, thus bringing certain features of poeticalness to the sonata, which is so characteristic of the Romantic composers.

The Sonata No.1 in fis-moll, perhaps, is the most romantic amongst others in its figurative and emotional structure, semantic concept, specifics of the musical dramaturgy. We agree with N.S. Nikolaeva who rightly claims that in the history of piano sonatas the Schumann' sonata in fismoll is "the most important link in the chain that concentrates romantic aesthetics and defines a new stage in the development of the genre" (Muzyka Avstrii i Germanii XIX veka, 1990: 41). 
Among the works of the sonata form, the value of this sonata is comparable to the Fantasia in C-dur. At the same time, in tension of the psychological conflict, the principles of dramaturgy in the fis-moll sonata, the composer gets on a par with the best sonatas by L. van Beethoven ("Moonlight Sonata", "Pathetique Sonata") extending threads to the b-moll sonata by Chopin - one of the greatest tragic sonatas in piano literature.

However, with the unity of creative settings, there are obvious differences in attitudes of the artists. In Schumann's work, despite the obvious embodiment of a pure romantic conflict with reality, yet a lyrical, deeply subjective principle moves in the foreground. His Sonata No.1 in fismoll is an acutely conflict lyrical monologue of the author's "dissociated" consciousness, which is confirmed by the composer's words, "It is a continuous cry of my soul for you", he wrote to Clara (Muzyka Avstrii i Germanii XIX veka, 1990: 178).

But the "confession of a bare soul" of such a great artist as R. Schumann inevitably goes beyond the narrow confines of just the individual and becomes a drama of a personality of the entire era: "Schumann's generalization takes the way of the confluence of the personal and psychological conflicts typical of his time to protest against the cruel abuse of feelings and high aspirations of soul. Chopin's generalization goes in the direction of the national-patriotic principle, Beethoven's the philosophical-revolutionary" (Muzyka Avstrii i Germanii XIX veka, 1990: 178).

The difference between Beethoven's and Schumann's concepts is in the dramatic features of the sonata, where the Florestan-Eusebius figurative and emotional polarity forms an individual look of the fis-moll sonata and, at the same time, makes it a summary work of musical romanticism.
A romantic concept of the sonata is implemented in a variety of ways - epigraphintroduction, different mottos, keynotes, keyintonations and key-rhythms, reminiscences, variant penetrations of thematic elements creating an internal thread of development, etc. Crosscutting themes or cells in unusual modifications enhance Schumann's romantic dramaturgy.

The interaction of the mentioned trends characterizes a number of works of romantic composers that differ by freedom of implementation of the sonata principles (ballads, Chopin's Fantasy, Liszt's sonatas and poems), which only emphasizes the importance of the Schumann's fis-moll sonata in the historical course of the development of the genre.

Pathosofthegeniuspersonality, inexhaustible depth of the composer's artistic world is defined by his commitment to everything that is "nonformat", "non-typed" in music. It has defined an innovative image of the piano compositions, conditioned creative findings of compositional solutions, unveiled excellence of the imaginative portrait characteristics: "The main nerve of Schumann's music is the fight between Florestan and Eusebius, the confrontation of these two contrasting principles in the human soul. A psychological scheme arising from this emerges in countless ways... Schumann introduced into music a new psychological groove, the unknownbefore nervousness and trepidation. Changes of emotional states, transitions of their nuances began to occur differently with Schumann" (Smirnov, 1990: 42).

P. Tchaikovsky, with his usual brilliant intuition, wrote, "We can say with confidence that the music of the second half of this century will be the period in the future history of art, which future generations will call Schumann's. Schumann's music that is organically adjacent to the creative work of Beethoven and, at the same time, is dramatically separated from it, opens up 
a whole new world of new musical forms, touches the strings that have not yet been touched by his great predecessors. There, we find an echo of the profound processes of our spiritual life, doubts, despairs and aspirations towards the ideal that overwhelm the heart of a modern man" (Konen, 1989: 310).
It did not take much time for his prediction to come true. Schumann's creative work, starting from the beginning of the $20^{\text {th }}$ century to the present day, consistently attracts both performers and researchers who are trying to break into the unique artistic world of the brilliant German romanticist.

\title{
References
}

Il'icheva, N. (2010). Metamorfozy khudozhestvennogo obraza (obraz Fausta v literature i muzyke [Metamorphoses of an artistic image (an image of Faust in literature and music)], In Voprosy kul'turologii [The Cultural Studies Issues], 1, 73-77.

Konen, V. (1989). Istoriia zarubezhnoi muzyki: vyp. 3 [History of foreign music: issue 3]. Moscow, $544 \mathrm{p}$.

Muzyka Avstrii i Germanii XIX veka: Kn. 2 [Music of Austria and Germany in the $1^{\text {th }}$ century: B. 2]. (1990) Moscow, $526 \mathrm{p}$.

Polezhaeva, Iu. (2014). Demonicheskie i infernal'nye obrazy v instrumental'nykh sochineniakh Ferentsa Lista: intonatsionnyi aspekt [Demonic and infernal images in instrumental compositions of Franz Liszt: intonational aspect], In Zhurnal Sibirskogo Federal'nogo Universiteta. Seria Gumanitarnye nauki. T. 7 [Journal of Siberian Federal University. Humanities, 7], 3, 525-536.

Schumann, R. (1970). Pis'ma. T. 1 (1817-1840) [Letters. Vol. 1 (1817-1840)]. Moscow, 320 p.

Smirnov, M. (1990). Emotsional'nyi mir muzyki [Emotional world of music]. Moscow, 250 p.

Zhitomirskii, D. (2000). Robert Shuman [Robert Schumann]. Moscow, 376 p.

\section{Соната fis-moll как пример романтического стиля музыки Р. Шумана}

\author{
О. Д. Доброшинская, М.В. Холодова \\ Красноярский государственный институт искусств \\ Россия, 660049, Красноярск, Ленина, 22
}

Роберт Шуман - яркий представитель эпохи романтизма. В данной статье рассматриваются особенности фортепианного стиля композитора в контексте романтического музыкального искусства, в частности сонаты для фортепиано №1 fis-moll - иентра субъективнолирических размыллений Шумана. В ней, как и в других фортепианных сочинениях "бурных» 30-х годов, нашло яркое отражение романтическое самосознание и запрограммированы ключевые принципы шумановского романтизма, сфокусированы основные черты творческого метода Р. Шумана, богатство эмоционально-образного строя, индивидуальность пианистической манеры.

Ключевые слова: Р. Шуман, музыкальный романтизм, романтический стиль, фортепианная соната.

Научная специальность: 24.00.00 - культурология. 